\title{
MODEL PENYUSUNAN BAHAN AJAR MEMBACA BERBASIS PENDIDIKAN MULTIKULTURAL DAN E-LEARNING
}

\author{
Endah Tri Priyatni dan Asnawi Susilo Wahono \\ Fakultas Sastra Universitas Negeri Malang \\ email: endahtri18@yahoo.com
}

\begin{abstract}
Abstrak
Penelitian ini bertujuan mengembangkan model panduan pembuatan bahan ajar membaca berbasis pendidikan multikultural dan e-learning. Penelitian ini menggunakan desain penelitian pengembangan model Recursive, Reflective Design and Development. Penelitian ini telah berhasil mengembangkan model panduan pengembangan bahan ajar membaca berbasis pendidikan multikultural dan dikemas dalam paket e-learning. Panduan tersebut berisi seperangkat aturan dan langkah-langkah yang perlu dipahami dan dilakukan guru dalam menyiapkan dan menyusun bahan ajar membaca berbasis pendidikan multikultural dan e-learning. Panduan dikemas dalam bentuk CD interaktif dan buku saku (booklet). Panduan telah diujicobakan kepada pengguna produk, validasi ahli, dan praktisi.
\end{abstract}

Kata kunci: pengembangan, membaca, multikultural, dan e-learning.

\section{A MODEL FOR DESIGNING READING INSTRUCTIONAL MATERIALS BASED ON MULTICULTURAL EDUCATION AND E-LEARNING}

\begin{abstract}
This study aims to develop a guide model for reading materials development based on multicultural education and e-learning. It employed a research and development design with Recursive, Reflective Design and Development. It successfully developed a guide model for reading materials development based on multicultural education which was in the form of an e-learning package. The guide contains a set of rules and steps that teachers should understand and carry out in preparing and developing reading materials based on multicultural education and e-learning. The guide is in the form of an interactive $\mathrm{CD}$ and booklet. It has been tried out to product users and validated by experts and practitioners.
\end{abstract}

Keywords: development, reading, multicultural, and e-learning.

\section{PENDAHULUAN}

Kemajemukan bangsa Indonesia dari segi bahasa, ras/etnik, budaya, dan agama adalah kehendak Tuhan sehingga harus dilihat sebagai anugerah dan kekayaan negeri ini. Namun, kemajemukan yang merupakan aset bangsa yang tidak ternilai harganya tersebut akan menjadi beban bangsa jika kepada para generasi mudanya tidak ditanamkan hidup dalam keberagaman sejak dini. Hal ini karena kemajemukan bisa menjadi pemicu mun- culnya konflik jika tidak dikelola dengan baik.

Saat ini, banyak konflik muncul disebabkan oleh faktor kemajemukan. Masyarakat yang dulu suka hidup rukun dan damai kini mudah tersulut api dendam. Sering kita lihat bentrokan antara desa satu dengan desa tetangganya hanya karena batas-batas wilayah, perbedaan agama, atau hal-hal kecil lainnya. Tindak kekerasan antarpelajar juga sering terjadi yang pemicunya adalah adanya dominasi 
antara pelajar satu dengan yang lainnya sehingga pelajar yang dominan seenaknya menganiaya pelajar yang terdominasi, dan konflik bernuansa etnis atau agama juga melanda sejumlah daerah (Kompas.com, 27 Februari 2010).

Konflik yang muncul karena faktor kemajemukan tersebut tidak bisa hanya ditanggapi dengan keprihatinan, tetapi harus segera dijawab. Salah satu jawabannya adalah dengan memasukkan pendidikan multikultural dalam kurikulum pendidikan formal dan nonformal sejak dini sebagai wahana untuk membangun karakter bangsa (Kompas.com. 27 Februari 2010). Pendidikan multikultural yang ditanamkan sejak dini akan menjadi fondasi bagi pengembangan masyarakat Indonesia yang lebih terbuka, toleran, dan demokratis.

Tujuan utama pendidikan multikultural adalah menumbuhkan toleransi pada keragaman budaya yang ada bukan untuk melaksanakan budaya lain, serta penanaman sikap kepada siswa tentang nilai-nilai multikultural, yaitu: toleransi, solidaritas, musyawarah, dan pengungkapan diri. Pendidikan multikultural tidak hanya terpaku pada dimensi kognitif atau pengetahuan, tetapi juga afektif dan psikomotorik (Kompas.com, Jumat, 9 April 2010).

Dalam konteks pembelajaran di kelas, kelas multikultural saat ini juga dipandang sebagai penghalang pencapaian prestasi secara optimal. Kelas multikultural adalah kelas-kelas yang siswasiswanya memiliki perbedaan latar belakang yang tajam, misalnya: perbedaan tigkat kecerdasan, suku, bahasa, agama, dan kelas sosial (Kathryn, 2002). Hasil penelitian menemukan ada lima masalah yang dihadapi oleh para pendidik yang mengajar pada kelas multikultural, yaitu (1) bagaimana memotivasi sekelompok siswa yang berbeda latar belakang: tigkat kecerdasan, suku, bahasa, agama, dan kelas sosial, (2) bagaimana mengajar se- cara efektif pada sekelompok siswa yang berbeda latar belakang: tigkat kecerdasan, suku, bahasa, agama, dan kelas sosial, (3) bagaimana mengajarkan perilaku yang responsif kepada sekelompok siswa yang berbeda latar belakang: tigkat kecerdasan, suku, bahasa, agama, dan kelas sosial, (4) bagaimana menghadapi siswa-siswa yang perbedaan kemampuannya sangat mencolok, dan (5) bagaimana menilai kemajuan siswa pada sekelompok siswa yang berbeda latar belakang: tigkat kecerdasan, suku, bahasa, agama, dan kelas sosial (Voelkl, Campbell, dan Masseo, 1999).

Menghadapi adanya beberapa perbedaan di atas, ada beberapa jalan pintas yang ditempuh sekolah, misalnya dengan mengelompokkan siswa yang pandai pada kelas tersendiri, misalnya: kelas $\mathrm{A}$, B, C adalah kelas untuk kelompok anak dengan tingkat kecerdasan tinggi, dan D, E, F adalah kelas untuk kelompok anak dengan tingkat kecerdasan sedang/ rendah. Kelas-kelas akselerasi yang ada pada suatu sekolah atau kelas 'internasional' yang ada pada suatu sekolah, dasar pengelompokannya adalah tingkat kecerdasan dan kelas sosial/kemampuan finansial orang tua.

Jalan pintas yang ditempuh oleh beberapa sekolah tersebut kurang sesuai dengan arah pendidikan multikultural yang sedang diupayakan penerapannya secara nyata dalam dunia pendidikan. Dalam konteks Indonesia, yang dikenal dengan muatan yang penuh dengan kemajemukan, kelas adalah wahana pendidikan multikultural. Kelas adalah salah satu wahana untuk menanamkan pendidikan multikultural. Pendidikan multikultural sangat strategis untuk dapat mengelola kemajemukan secara kreatif, sehingga konflik yang muncul sebagai dampak dari transformasi dan reformasi sosial dapat dikelola secara cerdas dan menjadi bagian dari pencerahan kehidupan bangsa ke depan. 
Dalam konteks pengembangan pendidikan multikultural di sekolah, pendikan multikultural berusaha mengidentifikasi dan menghilangkan adanya kepercayaan dan praktik diskriminasi di sekolah dan mendorong tumbuhnya persamaan dan keadilan sosial kepada semua orang tanpa melihat perbedaan budaya, suku, fisik, intelektual, dan kelas sosial (Waterworth, 2006). Pendidikan multikultural adalah sebuah proses pendidikan untuk membangun sikap saling menghargai antara sesama warga negara tanpa membedakan latar belakang etnik, ras, budaya, bahasa, dan agama serta aliran dalam beragama. Pendidikan multikultural juga diartikan proses pendidikan yang memberikan penghargaan sama antara semua siswa tanpa membedakan latar belakang etnik, ras, agama, budaya, bahasa, aliran keagamaan, dan bahkan strata sosial ekonomi masyarakat. Pendidikan multikultural dikembangkan dalam rangka memperkuat persatuan dan kesatuan, identitas nasional, dan citra bangsa di mata dunia internasional (Rosyada, 2008).

Beberapa piloting untuk implementasi pendidikan multikultural dilakukan oleh para praktisi di beberapa sekolah dasar (SD/MI) dan sekolah menengah (SMP/M.Ts dan SMA). Khusus implementasi pendidikan multikultural di SD/MI, difokuskan pada penanaman nilai toleransi, menghargai, empati, keadilan, dan kesetaraan (egaliter). Strategi dilakukan dengan mengintegrasikan VCD media Pustaka Anak Nusantara (budaya 32 provinsi) dalam pembelajaran IPA, Bahasa Indonesia, Pendidikan Kewarganegaraan dan Pengetahuan Sosial, Kerajinan Tangan dan Keterampilan, Agama, Akidah Akhlak, dan Matematika (Agustian, dkk., 2006).

Kendala yang dihadapi dalam implementasi pendidikan multikultural di sekolah adalah para guru menolak melaksanakan pendidikan multikultural karena takut menambah kurikulum yang menurut mereka sudah padat (Laporan Implementasi Pendidikan Multikultural, April 2008).

Mengingat pentingnya penanaman nilai-nilai multikultural siswa, yaitu agar siswa memiliki pemahaman dan keterampilan yang memadai untuk hidup berdampingan secara harmonis dan mampu mengelola keberagaman yang ada menjadi kekuatan dan kemajuan bangsa, maka perlu dicarikan strategi lain untuk menanamkan nilai-nilai multikultural. Salah satu strategi yang ditawarkan adalah dengan written currículum, yaitu dengan cara menyisipkan penanaman nilai-nilai multikultural dalam perangkat pembelajaran. Dengan menyisipkan nilainilai multikultural pada perangkat pembelajaran, guru tidak harus menambah jumlah mata pelajaran atau menambah jam pelajaran yang memang sudah padat. Perangkat pembelajaran yang digunakan sebagai media/sumber pembelajaran harus mampu memberikan penjelasan, contoh, dan ilustrasi untuk menanamkan nilai-nilai multikultural.

Untuk menjawab persoalan tersebut, telah dikembangkan satu perangkat pembelajaran untuk pembelajaran bahasa Indonesia, khususnya untuk pembelajaran membaca di SD/MI dalam penelitian ini pada tahun pertama. Penelitian ini pada tahun pertama telah menghasilkan dua produk, yaitu model materi pembelajaran dan model latihan pembelajaran berbasis e-learning. Hasil telaah ahli dan praktisi menunjukkan bahwa kedua produk ini dilihat dari kebenaran materi layak digunakan karena memiliki kesesuaian dengan SK dan KD, akurat dilihat dari ilmu membaca, memuat nilai-nilai multikultural yang dijabarkan dengan benar, dan tidak ada penjelasan atau materi yang salah konsep atau salah nalar, menarik, mudah digunakan, bahasa mudah dipahami, sistem koneksi (link) berfungsi dengan baik. Siswa sangat antusias dan

Model Penyusunan Bahan Ajar Membaca Berbasis Pendidikan Multikultural dan E-Learning 
menghabiskan banyak waktu untuk berinteraksi dengan produk yang dikemas dalam e-learning/ multimedia ini (Priyatni dan Wahono, 2009).

Produk yang telah dikembangkan pada tahun pertama tersebut juga telah diuji efektivitasnya pada tahun kedua. Uji efektivitas dilakukan untuk melihat efektivitas pembelajaran yang memanfaatkan produk yang dikembangkan dalam penelitian ini terhadap hasil pembelajaran membaca dan kemampuan menentukan sikap terkait dengan nilai-nilai multikultural.

Uji efektivitas dilakukan dengan rancangan praeksperimen, yaitu dengan pretes-postes kelompok tunggal, tanpa kelompok kontrol. Hasil analisis statistik uji $t$ menunjukkan perbedaan yang signifikan antara skor kemampuan membaca sebelum dan setelah perlakuan karena $\mathrm{P}<$ $\alpha 0,05$. Hasil analisis tersebut menunjukkan bahwa skor pretes dan postes berbeda secara signifikan. Perbedaan ini terjadi karena adanya perlakuan, yaitu dilaksanakannya pembelajaran membaca dengan menggunakan perangkat pembelajaran membaca berbasis pendidikan multikultural dan e-learning.

Dengan adanya perlakuan, skor kemampuan membaca siswa menjadi lebih tinggi dibandingkan dengan skor sebelum perlakuan. Dengan demikian dapat disimpulkan bahwa pembelajaran membaca dengan menggunakan perangkat pembelajaran membaca berbasis pendidikan multikultural dan e-learning berpengaruh secara signifikan terhadap hasil pembelajaran membaca. Temuan ini selaras dengan temuan para peneliti dari Edith Cowan University menyatakan bahwa hakikat dan bentuk interaksi yang digunakan dalam desain bahan multimedia mampu membangkitkan gairah belajar dan ingatan siswa (Leu, 2002).

Dari hasil analisis statistik uji $t$ juga dapat disimpulkan bahwa pembelajaran membaca dengan menggunakan perang- kat pembelajaran membaca berbasis pendidikan multikultural dan e-learning berpengaruh secara signifikan terhadap kemampuan menentukan sikap terkait penerapan nilai-nilai multikultural siswa SD dan MI.

Dari temuan ini dapat disimpulkan bahwa pembelajaran membaca dapat digunakan untuk menanamkan pendidikan mental dan kepribadian kepada para siswa, khususnya pendidikan multikultural. Pengintegrasian pendidikan multikultural dalam pembelajaran membaca ini terbukti efektif karena program pendidikan multikultural ini tidak berdiri sendiri. Komentar dari para siswa dan guru menyatakan bahwa dengan diintegrasikannya pendidikan multikultural dalam pembelajaran bahasa Indonesia, khususnya pembelajaran membaca, menyebabkan teks-teks bacaan menjadi menarik, memuat dan menanamkan nilainilai multikultural yang akan menjadi fondasi bagi pengembangan masyarakat Indonesia yang lebih terbuka, toleran, dan demokratis (Priyatni dan Wahono, 2010).

Penanaman nilai-nilai multikultural dalam perangkat pembelajaran ini menjadi menarik menurut siswa dan guru karena dikemas dalam bentuk cerita. Kemenarikan juga disebabkan oleh teks cerita dikembangkan dari perilaku negatif dan positif yang diambilkan dari contoh konkrit, yaitu contoh yang ada di sekeliling anak, dikenal atau dialami oleh anak-anak, bukan contoh yang bersifat abstrak.

Temuan penelitian ini membuktikan bahwa perangkat pembelajaran membaca berbasis pendidikan multikultural dan $e$ learning memiliki kontribusi nyata dalam meningkatkan kemampuan siswa dalam membaca dan meningkatkan kemampuan siswa dalam menentukan sikap terkait penerapan nilai-nilai multikultural.

Dari kedua penelitian tersebut memang telah dihasilkan produk berupa 
perangkat pembelajaran membaca berbasis pendidikan multikultural dan e-learning yang dapat dengan mudah digunakan oleh guru untuk melaksanakan pembelajaran. Namun, penelitian tersebut akan lebih berdaya guna dan berhasil guna apabila produk tersebut dilengkapi dengan panduan pengembangan perangkat pembelajaran bahasa Indonesia berbasis pendidikan multikultural dan e-learning. Melalui panduan yang dikembangkan ini diharapkan guru tidak hanya berperan sebagai pemakai tetapi sebagai desainer dan produser yang mengembangkan perangkat pembelajaran sesuai dengan kebutuhan pembelajar dan berbasis teknologi.

Panduan pengembangan perangkat pembelajaran bahasa Indonesia berbasis pendidikan multikultural dan e-learning yang dikembangkan ini untuk mengatasi kelangkaan perangkat lunak, khususnya untuk pembelajaran bahasa Indonesia. Temuan penelitian menunjukkan bahwa perangkat keras berupa komputer memang tersedia di sebagian besar SD/MI di Malang, namun perangkat lunaknya masih langka (Priyatni dan Wahono, 2010).

Panduan pengembangan perangkat pembelajaran bahasa Indonesia berbasis pendidikan multikultural dan e-learning berisi seperangkat aturan/kaidah dan langkah-langkah yang perlu dipahami dan dilakukan guru dalam menyiapkan dan menyusun perangkat pembelajaran bahasa Indonesia berbasis pendidikan multikultural yang dikemas dalam program e-learning.

Dengan dikembangkannya panduan tersebut diharapkan para guru terampil membuat perangkat pembelajaran berbasis pendidikan multikultural dan $e$ learning.

E-Learning sering pula dipahami sebagai suatu bentuk pembelajaran berbasis web yang bisa diakses dari intranet di jaringan lokal atau internet. Sebenarnya materi $e$-Learning tidak harus didistribusikan secara on-line baik melalui jaringan lokal maupun internet, distribusi secara off-line menggunakan media CD/DVD pun termasuk pola e-Learning. Dalam hal ini aplikasi dan materi belajar dikembangkan sesuai kebutuhan dan didistribusikan melalui media CD/DVD, selanjutnya pembelajar dapat memanfatkan CD/DVD tersebut dan belajar di tempat di mana dia berada.

Untuk dapat menghasilkan e-learning yang menarik dan diminati, Purbo (2002) mensyaratkan tiga hal yang wajib dipenuhi dalam merancang e-learning, yaitu: sederhana, personal, dan cepat. Sistem yang sederhana akan memudahkan peserta didik dalam memanfaatkan teknologi dan menu yang ada. Kemudahan pada panel yang disediakan akan mengurangi pengenalan sistem $e$ learning, sehingga waktu belajar peserta dapat diefisienkan untuk proses belajar dan bukan pada belajar menggunakan sistem e-learning. Syarat personal berarti pengajar dapat berinteraksi dengan baik seperti layaknya seorang guru yang berkomunikasi dengan murid di depan kelas. Dengan pendekatan dan interaksi yang lebih personal, peserta didik diperhatikan kemajuannya, serta dibantu segala persoalan yang dihadapinya. Hal ini akan membuat peserta didik betah berlamalama di depan layar komputer. Kemudian layanan ini ditunjang dengan kecepatan, respon yang cepat terhadap keluhan dan kebutuhan peserta didik lainnya. Dengan demikian perbaikan pembelajaran dapat dilakukan secepat mungkin oleh pengajar atau pengelola.

Cisco (2001) menjelaskan filosofi $e$ learning sebagai berikut. Pertama, e-learning merupakan penyampaian informasi, komunikasi, pendidikan, pelatihan secara on-line maupun offline. Kedua, e-learning menyediakan seperangkat alat yang dapat memperkaya nilai belajar secara konvensional sehingga dapat menjawab

Model Penyusunan Bahan Ajar Membaca Berbasis Pendidikan Multikultural dan E-Learning 
tantangan perkembangan globalisasi. Ketiga, e-learning tidak berarti menggantikan model belajar konvensional di dalam kelas, tetapi memperkuat model belajar tersebut melalui pengayaan isi dan pengembangan teknologi pendidikan. Keempat, kapasitas siswa amat bervariasi tergantung pada bentuk isi dan cara penyampaiannya. Makin baik keselarasan antara isi dan alat penyampai dengan gaya belajar, maka akan lebih baik kapasitas siswa yang pada gilirannya akan memberi hasil yang lebih baik.

E-learning memiliki karakteristik sebagai berikut: (1) memanfaatkan keunggulan komputer, (2) menggunakan bahan ajar bersifat mandiri (selflearning materials) disimpan di komputer sehingga dapat diakses oleh pengguna, (3) memiliki interaksi antara materi dengan pengguna, dan (4) memanfaatkan jadwal pembelajaran, kurikulum, hasil kemajuan belajar dan hal-hal yang berkaitan dengan administrasi pendidikan dapat dilihat setiap saat di komputer, dan (5) merupakan penyampaian informasi, komunikasi, pendidikan, pelatihan berbasis web yang disajikan baik secara on-line maupun offline.

\section{METODE}

Pada tahun pertama, penelitian ini bertujuan mengembangkan model materi dan model latihan pembelajaran membaca berbasis pendidikan multikultural dan e-learning yang dapat meningkatkan kemampuan membaca dan kemampuan menentukan sikap terkait penerapan nilai-nilai multikultural siswa SD/MI. Pada tahun kedua, penelitian ini bertujuan (1) mengkaji efektivitas perangkat pembelajaran membaca yang berbasis pendidikan multikultural dan e-learning dalam meningkatkan kemampuan membaca dan menentukan sikap terkait dengan penerapan nilai-nilai multikultural siswa SD/MI. Pada tahun III, penelitian ini bertujuan mengembangkan model panduan pembuatan bahan ajar mem- baca berbasis pendidikan multikultural dan e-learning. Panduan tersebut berisi seperangkat aturan dan langkah-langkah yang perlu dipahami dan dilakukan guru dalam menyiapkan dan menyusun bahan ajar membaca berbasis pendidikan multikultural dan e-learning. Panduan tersebut dikemas dalam bentuk $C D$ interaktif dan buku saku (booklet).

Panduan yang dikembangkan tersebut diharapkan dapat digunakan sebagai acuan para guru dalam mengembangkan bahan ajar berbasis teknologi mutakhir, yaitu multmedia interaktif dan dipakai sebagai acuan para trainer dalam melaksanakan pelatihan pembuatan bahan ajar berbasis teknologi mutakhir, yaitu multmedia interaktif berbentuk e-learning.

Untuk mencapai tujuan tersebut, penelitian ini pada tahun III menggunakan rancangan pengembangan karena tujuan penelitian ini adalah untuk mengembangkan model. Desain pengembangan yang digunakan diadopsi dari desain penelitian pengembangan model Recursive, Reflective Design and Development atau disingkat R2D2 (Willis, 1995).

R2D2 memiliki 4 prinsip, yaitu: (1) recursion, (2) reflection, (3) nonlinear, dan (4) desain partisipatori. Prinsip recursion, mengizinkan pengembang untuk menetapkan keputusan sementara dan meninjau kembali keputusannya tentang produk atau proses, setiap saat dalam perencanaan dan pengembangan produk, dan membuat perbaikan dan revisi jika diperlukan. Prinsip reflection, menuntut pengembang untuk merefleksi, memikirkan ulang secara sungguh-sungguh, mencari dan menemukan umpan balik dan ide-ide dari banyak sumber selama proses perancangan dan pengembangan. Prinsip nonlinear, mengizinkan pengembang untuk memulai pengembangan tidak secara urut dengan menggunakan format baku yang harus diikuti secara ketat mulai dari awal sampai dengan akhir. Sebagai contoh, pengembang dapat menetapkan 
tujuan sementara, dan tujuan, dikembangkan sepanjang proses dan mungkin bisa terjadi belum lengkap dan jelas sampai akhir proyek. Prinsip terakhir, desain partisipatori, pengembang melibatkan tim partisipan yang dilibatkan secara ekstensif dalam semua fase dari proses perencanaan dan pengembangan.

Model R2D2, sesuai untuk mengembangkan panduan/perangkat yang berbasis teknologi/e-learning. Hal ini karena untuk mengembangkan perangkat pembelajaran berbasis e-learning diperlukan editing dan refleksi berulang-ulang, sehingga diperlukan prinsip recursion dan reflection. Demikian juga dalam organisasi perangkat berbasis multimedia diperlukan program interaktif, yaitu pengguna dapat berinteraksi dengan program, dan prinsip nonlinear sangat tepat digunakan untuk pengembangan program berbasis multimedia. Untuk mengembangkan program berbasis multimedia diperlukan tim yang ahli di bidangnya masing-masing, karena itu prinsip partisipatif sangat tepat digunakan dalam pengembangan perangkat pembelajaran berbasis multimedia.

Selaras dengan prinsipnya yang nonlinear, prosedur pengembangan dalam model R2D2 bukan merupakan tahapan tetapi dinyatakan dalam bentuk fokus pengembangan. Ada tiga fokus dalam pengembangan ini, yaitu (1) fokus pen- etapan, (2) fokus penentuan desain dan pengembangan, dan (3) fokus diseminasi produk. Prosedur pengembangan dapat dilihat pada Bagan 1.

Penetapan adalah salah satu fokus pengembangan dalam model R2D2. Ada dua kegiatan pokok yang dilakukan pada fokus penetapan, yaitu (1) penetapan spesifikasi produk yang dikembangkan dan (2) penetapan tim partisipatif. Tim partisipatif dalam pengembangan ini adalah (1) tim ahli, (2) guru, dan (3) praktisi. Penentuan desain dan pengembangan adalah salah satu fokus pengembangan dalam model R2D2. Ada dua kegiatan pokok yang dilakukan pada fokus penentuan desain dan pengembangan, yaitu (1) persiapan dan (2) pengembangan. Pada tahap persiapan, ada tiga kegiatan yang dilakukan, yaitu (1) penentuan kisikisi pengembangan panduan bahan ajar membaca berbasis pendidikan multikultural dan e-learning, (2) penentuan materi, yaitu konsep, contoh, dan kegiatan, untuk pengembangan panduan bahan ajar membaca berbasis pendidikan multikultural dan e-learning, dan (3) penentuan media untuk menyajikan produk yang dikembangkan. Pada kegiatan pengembangan, ada dua kegiatan yang dilakukan, yaitu (1) pengembangan draf materi, yaitu konsep, contoh, dan kegiatan untuk pengembangan panduan bahan ajar membaca

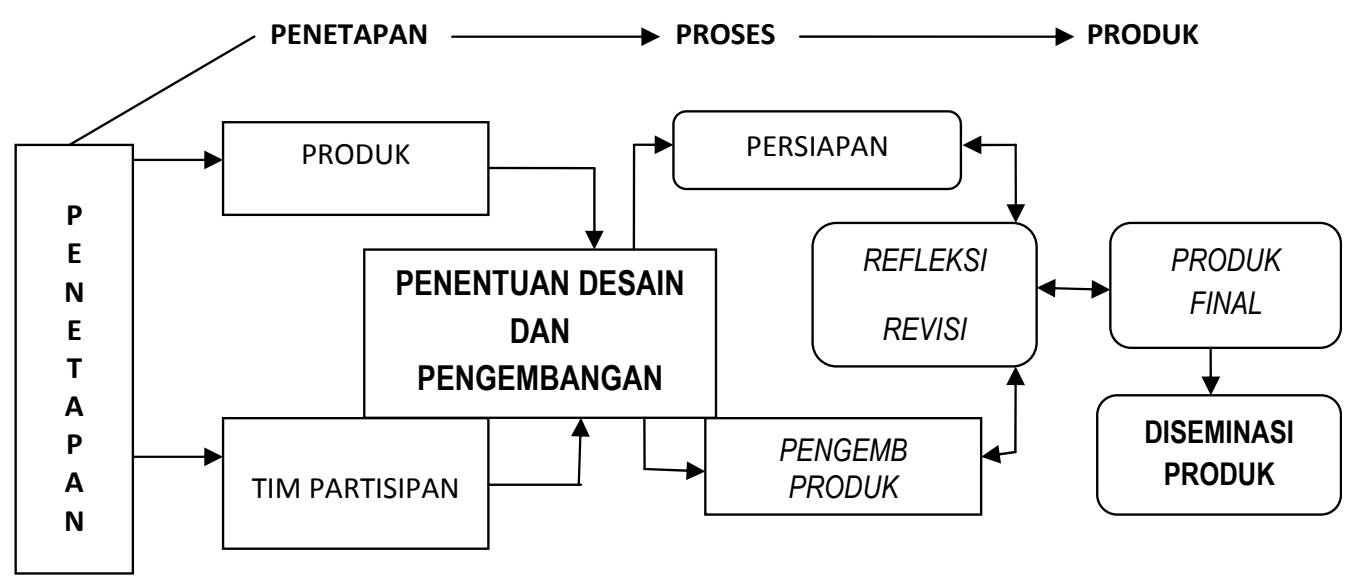

Bagan 1: Prosedur Pengembangan

Model Penyusunan Bahan Ajar Membaca Berbasis Pendidikan Multikultural dan E-Learning 
berbasis pendidikan multikultural dan (2) pengemasan panduan bahan ajar membaca berbasis pendidikan multikultural dalam paket multimedia.

Produk yang telah dikembangkan diujicobakan kepada (1) calon pengguna produk, yaitu 10 orang guru SD/MI, (2)uji ahli dan praktisi. Uji coba produk dalam model R2D2 bertujuan untuk memperoleh umpan balik. Umpan balik digunakan untuk dasar perbaikan produk yang telah dikembangkan (Willis, 1995). Umpan balik berupa kritik, komentar, dan saran. Produk yang telah direvisi kemudian dikemas dalam bentuk CD dan didiseminasikan kepada para pengguna produk dalam jumlah yang lebih besar, dengan cara diunggah (upload) di website: sastra. um.ac.id, http://www.um.ac.id.

Data pengembangan ini berupa data kualitatif, yaitu tanggapan (komentar, kritik, dan saran) dan penilaian dari tim partisipan selama proses pengembangan. Selaras dengan data pengembangan tersebut, sumber data kualitatif adalah seluruh tim partisipatif, yaitu 1 orang ahli pembelajaran membaca, 1 orang ahli multimedia, 1 orang praktisi multimedia, dan 10 orang guru SD/MI.

Dalam pengembangan ini, peneliti berperan sebagai instrumen kunci pada pengumpulan, analisis, dan penafsiran data. Dalam pengumpulan data kualitatif, peneliti menggunakan instrumen bantu berupa format catatan lapangan, panduan penelaahan produk, dan angket.

Analisis data dalam penelitian ini dipilah menjadi dua, yaitu analisis data dari hasil uji coba penerapan produk dan analisis data dari pakar/praktisi. Analisis data dari hasil uji coba produk dilakukan terhadap komentar, kritik, dan saran dari para calon pengguna produk selama proses uji coba berlangsung. Analisis data dilakukan dengan cara mengelompokkan data berdasarkan domain yang selaras dengan masalah penelitian, menafsirkan data, merefleksikan data, dan menyimpul- kan hasil analisis. Hasil analisis ini dipakai untuk menyempurnakan produk.

Analisis data dari pakar/praktisi dilakukan dengan teknik analisis domain. Data dikelompokkan berdasarkan cakupannya, yaitu dari aspek multimedia dan dari aspek isi. Masing-masing aspek dibedakan atas aspek telaah umum dan aspek telaah khusus. Perolehan data pada setiap kelompok data tersebut direfleksi untuk dibuat simpulan hasil analisis. Simpulan analisis tersebut dimanfaatkan untuk melakukan revisi produk.

\section{HASIL DAN PEMBAHASAN Model Panduan Pengembangan Bahan Ajar}

Penelitian ini telah berhasil mengembangkan model panduan pengembangan bahan ajar membaca berbasis pendidikan multikultural dan dikemas dalam paket e-learning. Panduan tersebut telah disusun sesuai dengan prosedur penelitian dan telah diujicobakan kepada pengguna produk, uji ahli, dan uji praktisi. Wujud panduan yang telah dikembangkan tersebut secara berturut-turut dipaparkan sebagai berikut.

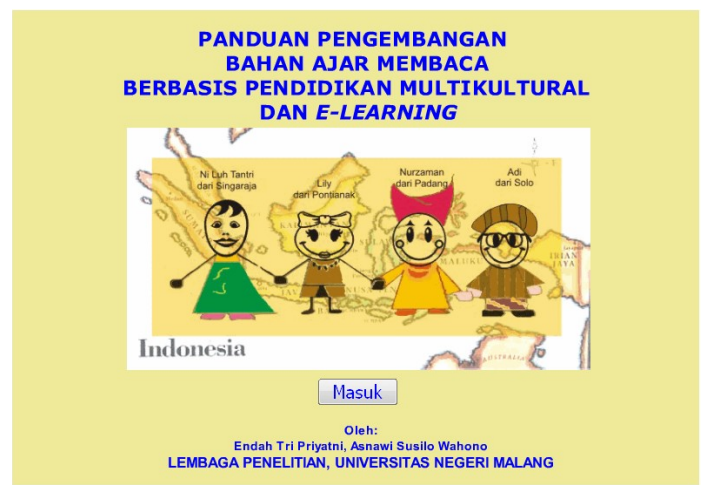

Gambar 1: Cover Program

Ketika ikon Panduan diklik satu kali, cover program beserta iringan musik akan muncul di layar, seperti tampak pada Gambar 1.

Pada Gambar 1 tertulis judul program, yaitu: PANDUAN PENGEMBANGAN 
BAHAN AJAR MEMBACA BERBASIS PENDIDIKAN MULTIKULTURAL DAN E-LEARNING. Di bawah judul terdapat gambar yang mencerminkan pendidikan multikultural, yaitu simbol masyarakat multicultural yang ada di Indonesia yang saling bergandengan tangan. Program juga dilengkapi dengan identitas penulis dan nama lembaga tempat peneliti mengabdikan diri.

Ketika ikon Masuk pada cover program diklik satu kali, akan muncul dua pilihan kegiatan, yaitu kegiatan untuk PENGGUNA PERTAMA atau kegiatan untuk PENGGUNA BERPENGALAMAN. Pengguna pertama adalah pengguna yang baru pertama kali membuka/mengoperasikan produk, sedangkan pengguna berpengalaman adalah pengguna yang telah berulangkali mengoperasikan produk ini, seperti tertera pada Gambar 2.

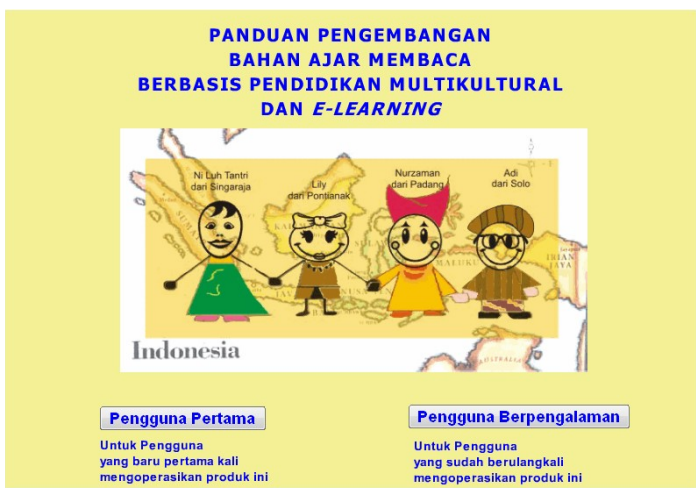

Gambar 2: Pengguna Pertama dan Pengguna Berpengalaman

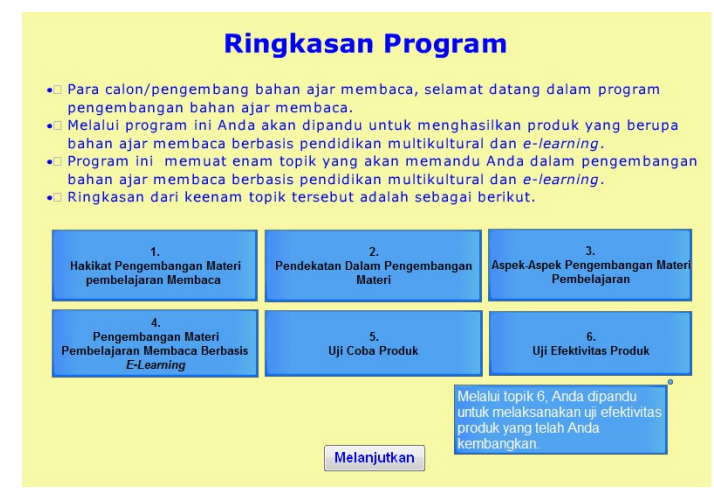

Gambar 3: Ringkasan Program

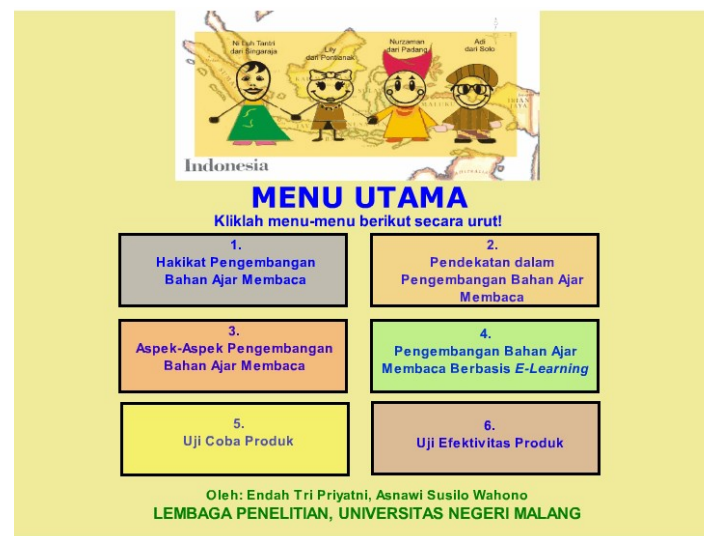

Gambar 4: Menu Utama

Ketika ikon PENGGUNA PERTAMA diklik satu kali, akan muncul ringkasan program. Ringkasan program memuat informasi tentang menu-menu yang disajikan pada keseluruhan program agar pembelajar memahami secara utuh keseluruhan isi program, seperti tampak pada Gambar 3.

Ketika ikon Melanjutkan diklik satu kali akan muncul Menu Utama. Pada JMenu Utama, tersaji semua menu program, yaitu enam topik yang disajikan dalam panduan, seperti dapat dilihat pada Gambar 4. Untuk pengguna pertama, harus mengeklik program ini secara urut.

Panduan utama memuat enam topik yang dirancang secara berkelanjutan. Keenam topik tersebut diuraikan berikut. Topik 1, memaparkan pengertian bahan ajar membaca, pengembangan bahan ajar membaca, tujuan pengembangan bahan ajar membaca, serta panduan untuk mengidentifikasi bahan ajar yang akan dikembangkan disertai dengan contohnya. Topik 2, memaparkan paradigma dalam pengembangan bahan ajar membaca dan panduan untuk mengidentifikasi target, desain, dan acuan yang digunakan dalam pengembangan beserta contohnya. Topik 3, memaparkan aspek-aspek yang dipersiapkan dalam pengembangan bahan ajar membaca dan panduan untuk mengembangkan draf bahan ajar membaca beserta contohnya. Topik 4, memaparkan konsep

Model Penyusunan Bahan Ajar Membaca Berbasis Pendidikan Multikultural dan E-Learning 
e-learning dan panduan untuk mengemas draf bahan ajar yang telah dikembangkan dalam paket e-learning disertai dengan contohnya. Topik 5, memaparkan tentang tujuan uji coba produk dan panduan untuk melaksanakan uji coba produk yang telah dikembangkan, disertai dengan contohnya. Topik 6, memaparkan tentang konsep dan tujuan uji efektivitas produk, panduan untuk melaksanakan uji efektivitas produk yang telah dikembangkan, disertai dengan contohnya. Keenam topik tersebut memberikan keterampilan utuh dan berkelanjutan agar para pengguna produk ini terampil mengembangkan bahan ajar secara profesional.

Seperti dijelaskan pada bahasan sebelumnya bahwa setiap topik pada panduan ini memuat tiga hal pokok, yaitu konsep, contoh, dan kegiatan. Ketika pengguna mengeklik Topik 1, 1. Hakikat Pengembangan Bahan Ajar, pengguna akan terhubung dengan 3 pilihan materi, yaitu (1) konsep, (2) contoh, dan (3) kegiatan, seperti tampak pada gambar 5 .

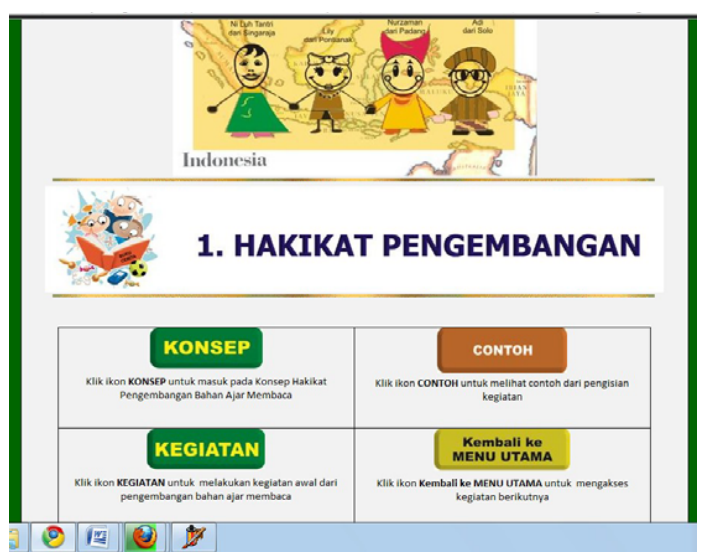

Gambar 5: Tiga Pilihan Materi Panduan

Ketika pengguna mengeklik ikon Konsep, sebanyak satu kali, ia akan terhubung dengan paparan tentang konsepkonsep esensial yang diperlukan dalam pengembangan bahan ajar, seperti tampak pada gambar 6 .

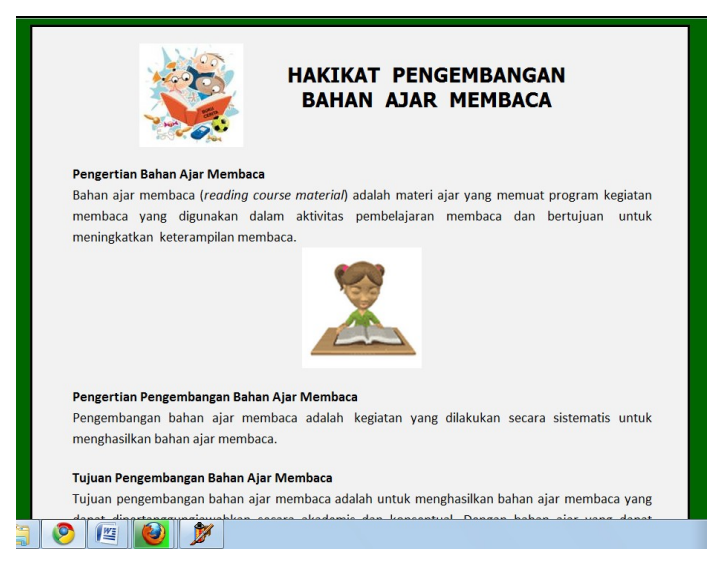

\section{Gambar 6: Konsep}

Ketika pengguna mengeklik ikon contoh, sebanyak satu kali, ia akan terhubung dengan contoh pengisian kegiatan, seperti tampak pada gambar 7 .

Ketika pengguna mengeklik ikon Kegiatan, sebanyak satu kali, ia akan terhubung dengan paparan tentang kegiatan-kegiatan yang harus dilaksanakan untuk menyiapkan dan menyusun produk, seperti tampak pada gambar 8 .

Selanjutnya, pengguna berpengalaman adalah pengguna yang sudah pernah mengoperasikan produk dan ingin menempuh jalan pintas dengan cara memilih program kegiatan sesuai dengan keinginan/kebutuhannya.

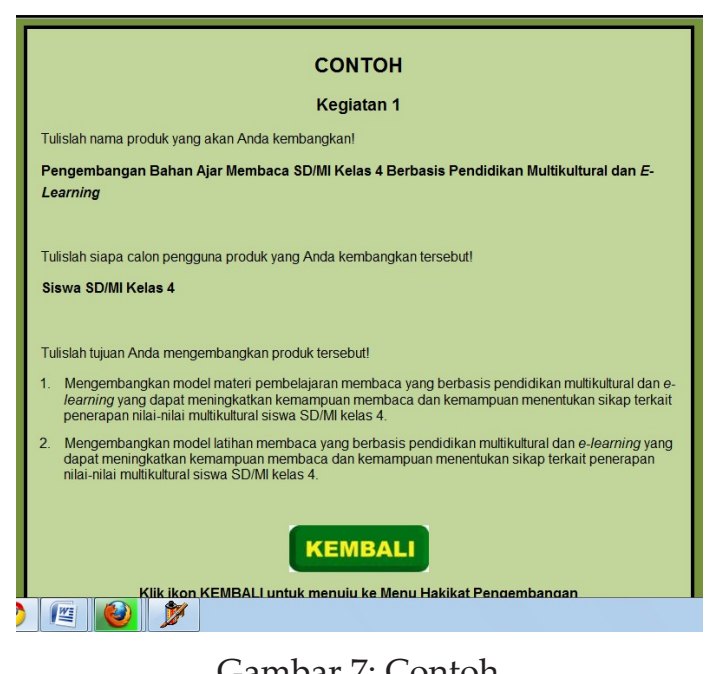

Gambar 7: Contoh 


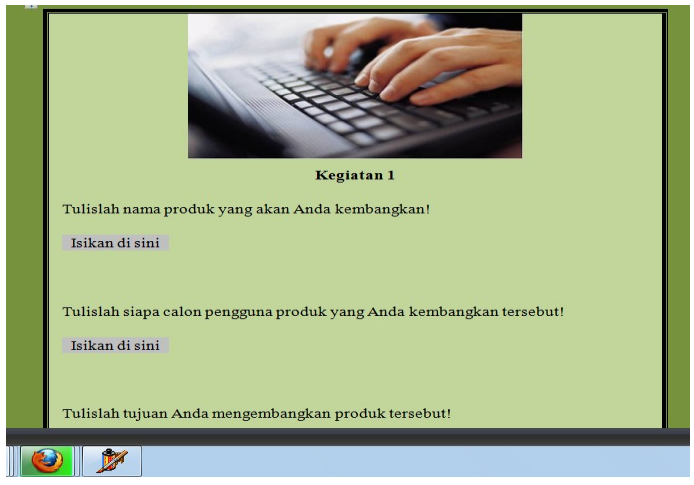

Gambar 8: Kegiatan

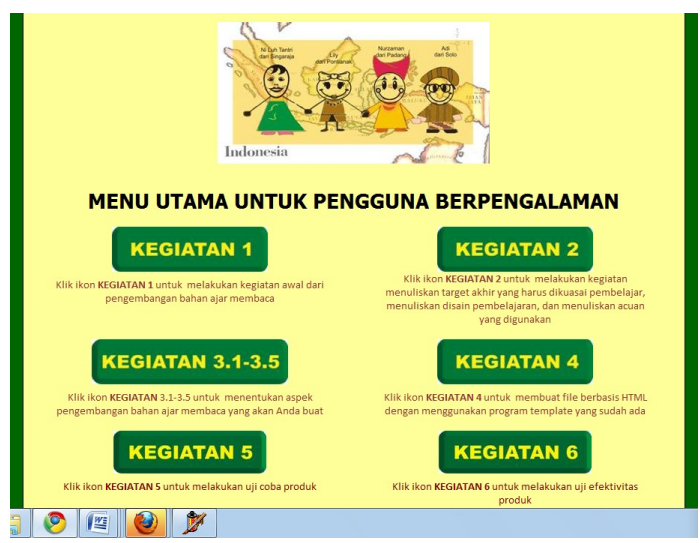

Gambar 9: Menu Kegiatan untuk Pengguna Berpengalaman

Ketika pengguna mengeklik ikon Pengguna Berpengalaman, pengguna akan terhubung dengan 6 Menu Kegiatan, seperti tampak pada Gambar 9.

\section{Produk Berbentuk Teori dan Praktik}

Berdasarkan deskripsi hasil pengembangan yang diuraikan di atas, tampak jelas bahwa panduan yang dikembangkan dalam penelitian ini tidak hanya mengajak pengguna untuk melaksanakan praktik menyiapkan dan menyusun bahan ajar, pengguna juga dibekali materi yang bersifat teoretis. Target akhir yang harus dikuasai oleh pengguna setelah mempelajari panduan ini adalah menguasai teori dan terampil melakukan praktik.

Pemilihan materi panduan yang berbentuk teori dan praktik ini selaras dengan tujuan pengembangan bahan ajar membaca adalah untuk menghasilkan bahan ajar membaca yang dapat dipertanggungjawabkan secara akademis dan konseptual. Untuk dapat menghasilkan bahan ajar yang dapat dipertanggungjawabkan secara akademis dan konseptual, pengguna harus dibekali wawasan teoretik, di samping praktik. Dengan wawasan teoretik ini diharapkan pengguna menjadi tenaga profesional bukan sekedar praktisi.

Mengingat pentingnya penguasaan teori dan sekaligus praktik dalam menyiapkan dan menyusun bahan ajar membaca, maka pengembangan bahan ajar berbentuk teori dan praktik ini sangat tepat. Hal ini didukung oleh hasil angket yang menyatakan bahwa $90 \%$ para calon pengguna produk terbantu dalam memahami konsep-konsep esensial yang diperlukan dalam pengembangan bahan ajar, sekaligus memeroleh contoh dan mampu melakukan praktik pengembangan bahan ajar. Melalui panduan ini mereka mendapatkan model bagaimana menyiapkan sampai dengan mengemas bahan ajar dalam paket e-learning.

Panduan ini memuat enam topik yang dirancang secara berkelanjutan. Melalui topik 1, pengguna diajak memahami pengertian bahan ajar membaca, pengembangan bahan ajar membaca, tujuan pengembangan bahan ajar membaca, serta dipandu untuk mengidentifikasi bahan ajar yang akan dikembangkan. Melalui topik 2, pengguna diajak mengenali paradigma dalam pengembangan bahan ajar membaca dan dipandu untuk mengidentifikasi target, desain, dan acuan yang digunakan dalam pengembangan. Melalui topik 3, pengguna diajak mengenali aspek-aspek yang dipersiapkan dalam pengembangan bahan ajar membaca dan dipandu untuk mengembangkan draf bahan ajar membaca. Melalui topik 4, pengguna diajak memahami konsep e-learning dan dipandu untuk mengemas draf bahan ajar yang telah dikembangkan dalam paket e-learning. Melalui topik 5,

Model Penyusunan Bahan Ajar Membaca Berbasis Pendidikan Multikultural dan E-Learning 
pengguna dipandu untuk melaksanakan uji coba produk yang telah dikembangkan. Melalui topik 6, pengguna dipandu untuk melaksanakan uji efektivitas produk yang telah dikembangkan. Dengan menggunakan panduan yang memberikan keterampilan utuh dan berkelanjutan ini, diharapkan pengguna terampil mengembangkan bahan ajar secara profesional.

Hasil angket menunjukkan bahwa 80\% pengguna produk merasa senang dengan panduan yang utuh dan berkelanjutan ini karena dengan panduan ini mereka merasakan memiliki wawasan yang utuh (tidak hanya setengah-setengah) terkait dengan pengembangan bahan ajar, mulai dari tahap persiapan, tahap pelaksanaan, uji coba, sampai dengan uji efektivitas produk.

Pada awal pengembangan, produk tidak dilengkapi dengan contoh. Tanpa contoh, ternyata para pengguna produk kesulitan melaksanakan kegiatan yang terdapat dalam panduan. Setelah produk dilengkapi dengan contoh, para pengguna mampu menghasilkan produk-produk yang lebih baik. Contoh-contoh yang disajikan pada setiap topik berperan sebagai pemodelan.

Pemodelan adalah salah satu prinsip penting dalam pengajaran dan pembelajaran. Pemodelan diartikan oleh Oka (2002) sebagai kegiatan guru dalam memberikan contoh, memeragakan, atau mendemontrasikan. Tujuan pemodelan adalah agar pembelajar mengetahui, melihat, dan dapat melakukan dengan baik hal yang dicontohkan oleh si pemodel (Oka, 2002). Tujuan pemodelan juga untuk membahasakan gagasan yang kita pikirkan, mendemonstrasikan bagaimana kita menginginkan para pembelajar seharusnya belajar, atau melakukan apa yang kita inginkan agar siswa melakukannya (C. Star, 2001). Hasil angket menunjukkan bahwa $90 \%$ para pengguna sangat terbantu dengan adanya contoh yang disajikan dalam panduan.
Dari hasil uji coba, pengguna sangat antusias dengan menghabiskan banyak waktu untuk berinteraksi dengan produk yang dikemas dalam paket multimedia. Mereka tidak hanya mengoperasikannya di laboratorium komputer tetapi juga mengopinya untuk dipelajari secara mandiri di rumah. Ini berarti produk ini sudah berhasil membangkitkan minat pengguna. Para guru dari mata pelajaran lain dan dari sekolah lain sangat antusias mengopi produk ini untuk diadaptasi guna mengembangkan bahan ajar pada mata pelajaran lain. Berdasarkan hasil angket yang diberikan kepada calon pengguna produk, $80 \%$ calon pengguna produk menyatakan senang belajar dengan menggunakan produk berbasis multimedia ini. Produk yang berbasis multimedia/ e-learning ini juga memiliki kelemahan yang harus diwaspadai, yaitu serangan virus yang menyebabkan produk tidak dapat dioperasikan.

Panduan ini, di samping memiliki beberapa kelebihan seperti yang telah diuraikan di atas, juga memiliki beberapa kelemahan. Salah satu kelemahan panduan ini adalah untuk kegiatan 3.5-3.6 diperlukan pendampingan. Hal ini karena tidak setiap pengguna produk dapat melaksanakan kegiatan memilih teks, uji keterbacaan, menyusun pertanyaan, pilihan jawaban, beserta kunci jawabannya dengan benar. Demikian juga untuk kegia$\tan 6$, tidak setiap pengguna produk dapat melaksanakan uji beda dengan program SPSS for Windows. Untuk mengatasi kelemahan tersebut, produk dilengkapi dengan lampiran yang memberikan contoh cara menganalisis dan cara menjalankan program SPSS.

Produk yang telah direvisi kemudian dikemas dalam bentuk $C D$ dan diupload di website UM:sastra.um.ac.id. Di samping itu, produk manual juga telah dikemas dalam bentuk buku dan diajukan ke penerbit untuk diterbitkan. Diseminasi dimaksudkan agar produk dapat dimanfaatkan oleh khalayak/pengguna yang lebih luas. 


\section{SIMPULAN}

Panduan pengembangan bahan ajar membaca berbasis pendidikan multikultural dan e-learning adalah produk yang dihasilkan dalam penelitian pengembangan ini. Produk tersebut memuat enam topik, yaitu: (1) topik 1, memaparkan tentang pengertian bahan ajar membaca, pengembangan bahan ajar membaca, tujuan pengembangan bahan ajar membaca, serta panduan untuk mengidentifikasi bahan ajar yang akan dikembangkan, (2) topik 2, memaparkan tentang paradigma dalam pengembangan bahan ajar membaca dan panduan untuk mengidentifikasi target, desain, dan acuan yang digunakan dalam pengembangan, (3) topik 3, memaparkan tentang aspek-aspek yang dipersiapkan dalam pengembangan bahan ajar membaca dan panduan untuk mengembangkan draf bahan ajar membaca, (4) topik 4, memaparkan tentang konsep e-learning dan panduan untuk mengemas draf bahan ajar yang telah dikembangkan dalam paket e-learning, (5) topik 5, memaparkan tentang tujuan uji coba produk dan panduan untuk melaksanakan uji coba produk yang telah dikembangkan, (6) topik 6, memaparkan tengan konsep uji efektivitas produk dan panduan untuk melaksanakan uji efektivitas produk yang telah dikembangkan.

Dari uraian di atas dapat disimpulkan bahwa keenam topik yang dikembangkan dalam panduan tersebut bersifat utuh dan berkelanjutan. Keenam topik tersebut diperlukan untuk menyiapkan dan membuat bahan ajar membaca berbasis pendidikan multikultural dan e-learning.

Panduan pengembangan bahan ajar membaca berbasis pendidikan multikultural dan e-learning ini memuat konsep, contoh, dan kegiatan. Konsep berisi paparan teoretis tentang hakikat bahan ajar dan pengembangan bahan ajar, paradigma dalam pengembangan bahan ajar, aspekaspek pengembangan bahan ajar, konsep e-learning dan multimedia, pengertian dan tujuan uji coba produk, pengertian dan tu- juan uji efektivitas produk. Contoh berisi paparan tentang contoh konkrit hal-hal yang harus dipersiapkan untuk pengembangan bahan ajar dan contoh bahan ajar. Kegiatan berisi tugas-tugas yang harus dilaksanakan oleh para pengguna produk dalam menyiapkan dan menyusun bahan ajar membaca berbasis pendidikan multikultural dan e-learning.

Berdasarkan diuraikan di atas dapat disimpulkan bahwa panduan yang dikembangkan dalam penelitian ini tidak hanya mengajak pengguna untuk melaksanakan praktik menyiapkan dan menyusun bahan ajar, pengguna juga dibekali materi yang bersifat teoretis. Target akhir yang harus dikuasai oleh pengguna setelah mempelajari panduan ini adalah menguasai teori dan terampil melakukan praktik.

\section{UCAPAN TERIMA KASIH}

Dalam menyelesaikan laporan penelitian ini, kami banyak mendapatkan bantuan, sumbangan pikiran, dan tenaga dari berbagai pihak. Untuk itu, kami ucapkan terima kasih kepada pihak-pihak berikut. Pertama, ucapan terima kami sampaikan kepada Direktur DP2M Dikti yang telah memberi kesempatan kepada kami untuk melaksanakan penelitian, sehingga kami berkesempatan untuk mengembangkan panduan penyusunan bahan ajar membaca berbasis pendidikan multikultural dan e-learning pada tahun III ini. Kedua, ucapan terima kami sampaikan kepada Lembaga Penelitian Universitas Negeri Malang yang telah memfaslitasi kami untuk melaksanakan dan menyelesaikan laporan penelitan ini. Ketiga, ucapan terima kami sampaikan kepada Dekan Fakultas Sastra dan Ketua Jurusan Sastra Indonesia yang telah memberikan izin untuk melaksanakan penelitian ini. Keempat, ucapan terima kami sampaikan kepada Prof. Dr. H. A. Achmad Fatchan, M.Pd., M.P., Prof. Dr. H. Abdul Syukur Ibrahim, dan Dr. Hj. Yuni Pratiwi, M.Pd., selaku reviewer, yang telah banyak mem-

Model Penyusunan Bahan Ajar Membaca Berbasis Pendidikan Multikultural dan E-Learning 
berikan masukan dan koreksi yang sangat bermanfaat demi perbaikan proses dan hasil penelitian ini. Kelima, ucapan terima kami sampaikan kepada para pakar dan praktisi serta para guru MI Imami Kepanjen dan MI NU Sumberpasir, yang telah dengan penuh antusias dan semangat bersedia menjadi subjek coba dan menelaah produk yang kami kembangkan ini. Keenam, ucapan terima kami sampaikan kepada Kepala MI Imami Kepanjen dan MI NU Sumberpasir Kabupaten Malang, yang telah berkenan memberikan izin untuk melaksanakan uji coba produk yang kami kembangkan ini di kedua sekolah tersebut. Mudah-mudahan temuan penelitian ini bermanfaat bagi para pemerhati pengajaran Bahasa Indonesia dan semua pihak yang terlibat dan bertanggung jawab terhadap perencanaan dan pelaksanaan pembelajaran bahasa Indonesia, khususnya di jenjang sekolah dasar.

\section{DAFTAR PUSTAKA}

Agustian, Murniati. 2008. "Pengembangan Model Pendidikan Multikultural untuk Anak Usia Dini dengan Menggunakan Seri Pustaka Anak Nusantara." Makalah disajikan dalam Semlok Pendidikan Multikultural.

Asy'arie, Musa. Tanpa Tahun. "Pendidikan Multikultural dan Konflik Bangsa". Kompas.com. diunduh, 9 April 2010.

Depdiknas. 2006. Standar Isi. Jakarta: Departemen Pendidikan Nasional

Donohue, P.I.,K.E. Campbell, J.R., dan Mazzeo, J. 1999. NAEP 1999 reading report card for the nation and the states. Washington, DC: National Center for Education Statistics, U.S. Department of Education.

Kathryn. 2002. "Multicultural Factors and the Effective Instruction of Students of Diverse Background". Dalam Alan E. Farstrup dan S.Jay Samuels (Eds.). What Research has to Say about Reading Instruction. Newark, Delaware: Reading Association.
Leu, Donald J. 2002. “The New Literacies: Research on Reading Instruction With the Internet". Dalam Alan E. Farstrup dan S.Jay Samuels (Eds.). What Research has to Say about Reading Instruction. Newark, Delaware: Reading Association.

Marshall, Nicola; Caygill, Robin; dan May, Steve. 2008. PISA 2006: Reading literacy - How ready are our 15-year-olds for tomorrow's world? www. PISA.org.

Nunan, David. 1999. Second Language Teaching and Learning. Boston: Heinle \& Heinle Publishers.

Oliver, Ron. 2002. "Interactions in multimedia learning materials:The things that matter. Diakses dari http://www. aset.org.au/confs/iims/1996/lp/oliver. html

Oka, Djoehana D. 2002. "Modeling. Kumpulan Materi TOT CTL Mata Pelajaran Bahasa Inggris". Departemen Pendidikan Nasional. Direktorat Jendral Pendidikan Dasar dan Menengah. Direktorat Pendidikan Lanjutan Pertama.

Romiszowsky, A.J. 1988. The Selection and Development of Instructional Material. Loncon: Nicholas Publishing.

Rosyada, Dede. 2008. “Pendidikan Multi Kultur: Apa, Mengapa, dan Bagaimana. Makalah disajikan dalam Semlok Pendidikan Multikultural". Ditjen Pendidikan Islam Departemen Agama, Jakarta, Senin, 25 Februari 2008.

Waterworth, Peter. 2006. "Developing Multicultural Education in Indonesia". Makalah disajikan dalam Seminar Internasional tentang Pendidikan Multikultural yang dilaksanakan 11 Februari 2006 di Sekolah Laboratorium Universitas Negeri Malang.

Willis, J. 1995. "A Recursive, Reflective Instructional Design Model Based on Constructivist-Interpretivist Theory". Educational Technology, 35 (6), 5-23.

Yardi, Lidus. 2003. "Membangkitkan Minat Baca". Lidus Yardi S.Pd.I (Email) 